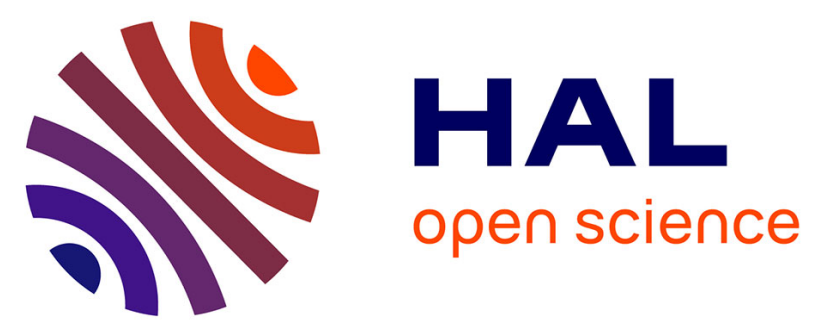

\title{
Temporal isolation explains host-related genetic differentiation in a group of widespread mycoparasitic fungi
}

Levente Kiss, Alexandra Pintye, Gabor Kovacs, Tünde Jankovics, Michaël Fontaine, Nick Harvey, Xiangming Xu, Philippe C. Nicot, Marc Bardin, Jacqui A. Shykoff, et al.

\section{To cite this version:}

Levente Kiss, Alexandra Pintye, Gabor Kovacs, Tünde Jankovics, Michaël Fontaine, et al.. Temporal isolation explains host-related genetic differentiation in a group of widespread mycoparasitic fungi. Molecular Ecology, 2011, 20 (7), pp.1492-1507. 10.1111/j.1365-294X.2011.05007.x . hal-02329042

\section{HAL Id: hal-02329042 \\ https://hal.science/hal-02329042}

Submitted on 29 May 2020

HAL is a multi-disciplinary open access archive for the deposit and dissemination of scientific research documents, whether they are published or not. The documents may come from teaching and research institutions in France or abroad, or from public or private research centers.
L'archive ouverte pluridisciplinaire HAL, est destinée au dépôt et à la diffusion de documents scientifiques de niveau recherche, publiés ou non, émanant des établissements d'enseignement et de recherche français ou étrangers, des laboratoires publics ou privés. 
Version définitive du manuscrit publié dans / Final version of the manuscript published in : Molecular Ecology, 2011, 20:7, 14921507, DOI: 10.1111/j.1365-294X.2011.05007.x. The definitive version is available at www3.interscience.wiley.com.

\title{
Temporal isolation explains host-related genetic differentiation in a group of widespread mycoparasitic fungi
}

\author{
LEVENTE KISS,* ALEXANDRA PINTYE,* GÁBOR M. KOVÁCS,*† TÜNDE \\ JANKOVICS, * MICHAEL C. FONTAINE, $\ddagger$ NICK HARVEY,§ XIANGMING XU,- \\ PHILIPPE C. NICOT, ${ }^{* *}$ MARC BARDIN, ${ }^{* *}$ JACQUI A. SHYKOFF $\ddagger$ and TATIANA \\ GIRAUD $\ddagger$
}

*Plant Protection Institute of the Hungarian Academy of Sciences, P.O. Box 102, H-1525 Budapest, Hungary, †Department of Plant Anatomy, Eötvös Loránd University, Pázmány Péter Sétány 1/C, H1117 Budapest, Hungary, ¥Laboratoire Ecologie, Systématique et Evolution, Université de Paris-Sud; CNRS; and AgroParisTech, UMR 8079, Orsay Cedex F-91405, France, §Genetic Marker Services, 7 Windlesham Road, Brighton BN1 3AG, UK, -East Malling Research, New Road, East Malling, Kent ME19 6BJ, UK, **INRA, UR407, Unité de Pathologie Végétale, Domaine St Maurice, 84140 Montfavet, France

\begin{abstract}
Understanding the mechanisms responsible for divergence and specialization of pathogens on different hosts is of fundamental importance, especially in the context of the emergence of new diseases via host shifts. Temporal isolation has been reported in a few plants and parasites, but is probably one of the least studied speciation processes. We studied whether temporal isolation could be responsible for the maintenance of genetic differentiation among sympatric populations of Ampelomyces, widespread intracellular mycoparasites of powdery mildew fungi, themselves plant pathogens. The timing of transmission of Ampelomyces depends on the life cycles of the powdery mildew species they parasitize. Internal transcribed spacer sequences and microsatellite markers showed that Ampelomyces populations found in apple powdery mildew (Podosphaera leucotricha) were genetically highly differentiated from other Ampelomyces populations sampled from several other powdery mildew species across Europe, infecting plant hosts other than apple. While P. leucotricha starts its life cycle early in spring, and the main apple powdery mildew epidemics occur before summer, the fungal hosts of the other Ampelomyces cause epidemics mainly in summer and autumn. When two powdery mildew species were experimentally exposed to Ampelomyces strains naturally occurring in P. leucotricha in spring, and to strains naturally present in other mycohost species in autumn, cross-infections always occurred. Thus, the host-related genetic differentiation in Ampelomyces cannot be explained by narrow physiological specialization, because Ampelomyces were able to infect powdery mildew species they were unlikely to have encountered in nature, but instead appears to result from temporal isolation.
\end{abstract}

Keywords: biotrophic pathogens, isolation in time, speciation, tri-trophic interactions 
Version définitive du manuscrit publié dans / Final version of the manuscript published in : Molecular Ecology, 2011, Article first published online, DOI: 10.1111/j.1365-294X.2011.05007.x. The definitive version is available at www3.interscience.wiley.com.

\section{Introduction}

The existence of closely related species parasitizing different hosts is a widespread phenomenon among parasites (de Meeûs et al. 1998). Understanding the underlying evolutionary mechanisms responsible for specialization and speciation of these parasites is a major challenge in evolutionary biology and is especially relevant in the context of the emergence of new diseases via host shifts. The formation of sibling species on different hosts must often require new adaptations allowing exploitation of novel hosts, but these adaptations are seldom sufficient to generate reproductive isolation that will allow speciation in sexual organisms (Johnson et al. 1996; Giraud 2006a,b; Giraud et al. 2008b). Indeed, although selection can maintain differentiation at loci involved in adaptation (Levene 1953), the rest of the genome will still homogenize unless barriers to gene flow exist. For species formation, gene flow must cease over large parts, if not all, of the genome. Extrinsic barriers such as allopatry will cause this, but so can intrinsic barriers to gene flow, including mating partner choice, host choice for parasites that mate within their hosts and temporal isolation for parasites with different times of emergence (Théron \& Combes 1995). Some parasites have life cycles that allow simple adaptation to cause differentiation over the whole genome. First, in sexual parasites that cannot disperse between development on the host and mating, such as many fungi belonging to the Ascomycota, adaptation can act as a 'magic trait' (Gavrilets 2004), pleiotropically causing reproductive isolation (Giraud et al. 2006, 2008a,b, 2010; Le Gac \& Giraud 2008), because these parasites must mate on the host where they grew, they can only mate with other individuals adapted to the same host. Second, in asexual species, recombination cannot break association between the genes under selection and the rest of the genome (Fisher et al. 2005; Giraud et al. 2008a). Adaptation can thus cause the formation of clonal lineages adapted to different host plants. The conceptual difficulty posed by asexual organisms is understanding how discrete entities that we recognize as species, rather than continuous distributions of phenotypes/genotypes, exist. Asexual organisms do appear to form discrete species (Fontaneto et al. 2007), and the hypotheses invoked to explain this despite lack of homogenizing gene flow include the existence of discrete ecological niches and random processes of extinctions of intermediate genotypes/phenotypes (Coyne \& Orr 2004).

To understand the formation of host-specific pathogen species, we therefore have to: (i) determine whether sex occurs regularly, by using molecular markers to look for footprints of recombination; the observation of the presenceabsence of the sexual fruiting bodies is not reliable information, especially in pathogenic fungi (Taylor 1999; Giraud et al. 2008a); (ii) if sex occurs, identify barriers to gene flow, and there may be multiple barriers (de Vienne et al. 2009); (iii) if there is no sex, one must explain the lack of dispersal among different hosts and how discrete and distinct clusters have been formed and are maintained.

Mycoparasites, i.e. fungi parasitizing other fungi, pro- vide an excellent model for investigating these questions. The genus Ampelomyces consists of intracellular mycoparasites of powdery mildew fungi (the Erysiphales), well-known pathogens of monocotyledonous and dicotyledonous plant species, including important crops (Kiss et al. 2004; Kiss 2008). This interaction takes place exclusively on aerial plant surfaces, facilitating direct observation (Kiss 1998, 2001). Masses of intracellular pycnidia of Ampelomyces, mostly produced in the cells of the powdery mildew conidiophores, are sometimes visible even to the naked eye as brownish patches in the white powdery mildew mycelium that covers the leaves, stems and other aerial parts of host plants (Kiss 2008). The sexual stage of these fungi remains unknown. Their life cycle, including short- and long- distance dispersal, is summarized in Fig. S1 (Supporting information).

The natural occurrence of Ampelomyces was reported in more than 66 powdery mildew species worldwide (Falk et al. 1995; Kiss 1998), but it is still unclear whether several distinct Ampelomyces species exist and, if so, whether these are specialized to the mycohost species and/or the host plant species on which they were found (Park et al. 2010). Cross- 
Version définitive du manuscrit publié dans / Final version of the manuscript published in : Molecular Ecology, 2011, Article first published online, DOI: 10.1111/j.1365-294X.2011.05007.x. The definitive version is available at www3.interscience.wiley.com.

inoculation experiments have repeatedly shown that Ampelomyces mycoparasites collected from a given powdery mildew host can readily infect other host species (Sztejnberg et al. 1989; Kiss et al. 2004; Szentiványi et al. 2005; Liang et al. 2007; Kiss 2008). In fact, strains with identical genotypes for their internal transcribed spacer (ITS) region of the nuclear ribosomal DNA (rDNA) have been collected from several powdery mildew species infecting different plant hosts in distant parts of the globe (Szentiványi et al. 2005; Liang et al. 2007; Park et al. 2010). On the other hand, Ampelomyces strains isolated from the same or different powdery mildew species can show sequence divergence values for this same genetic marker as high as 10-15\% (Kiss \& Nakasone 1998; Sullivan \& White 2000; Szentiványi et al. 2005; Liang et al. 2007; Park et al. 2010). In other ascomycetous fungi, divergence among sister species is usually less than 5-10\% for ITS sequences although this varies among groups (Seifert et al. 1995; Nilsson et al. 2008). Ampelomyces ITS haplotypes predicted neither the powdery mildew species nor the host plant species from which they came, with one exception: Ampelomyces strains obtained from apple powdery mildew (APM, caused by Podosphaera leucotricha). The ITS sequences of all the European APM strains studied so far were identical and divergent from those of the most closely related ITS haplotype. Furthermore, this haplotype was found almost exclusively in APM, having been detected only in one European and one Korean non-APM strain isolated from Podosphaera pannosa infecting other rosaceous hosts (Szentiványi et al. 2005; Park et al. 2010). Such high genetic differentiation in natural populations suggests that Ampelomyces infecting APM in nature is distinct from congeneric mycoparasites infecting other host species. However, this was only shown based on ITS data in a few APM strains (Szentiványi et al. 2005). Curiously, despite the apparent almost strict host specificity of this particular Ampelomyces ITS haplotype in nature, APM strains readily infected tobacco powdery mildew, caused by Golovinomyces orontii, following artificial inoculation (Szentiványi et al. 2005).

Why should there be an isolated lineage of Ampelomyces on APM, but no clear evidence for specialization or isolation of Ampelomyces on other powdery mildew hosts? What has allowed the APM Ampelomyces lineage to diverge extensively genetically despite its ability to infect other powdery mildew fungi that share a common geographical range? Here, we explore the possibility that the APM Ampelomyces lineage is a distinct cryptic species separated from other Ampelomyces lineages by temporal isolation. APM usually completes its life cycle in spring and early summer, while most other powdery mildew species start their life cycle later in the season (Szentiványi et al. 2005). Although theoretical studies have proposed temporal isolation as a sympatric speciation mechanism in flowering plants (Stamm 1983; Devaux \& Lande 2008) and there is some evidence that temporal isolation plays a role in reducing gene flow in schistosomes (Théron \& Combes 1995), plant pathogenic fungi (Van Putten et al. 2007; Montarry et al. 2008, 2009) and phytophagous insects (Berlocher \& Feder 2002; Thomas et al. 2003), we do not know how general this mechanism may be, and if it alone can be strong enough to allow divergence. Therefore, elucidating whether sympatric species of Ampelomyces could be isolated by host phenology represents an important advance in our understanding of ecological speciation that remains one of the most controversial topics in studies of speciation (Gavrilets \& Losos 2009; Giraud et al. 2010).

To test the hypothesis of the existence of cryptic species separated by temporal isolation, we addressed the following questions: (i) Is there genetic differentiation between Ampelomyces mycoparasites isolated in spring (mostly APM isolates) and autumn (isolates coming from many other mycohosts) in the same locations? (ii) Do these mycoparasites reproduce sexually? (iii) Can spatial isolation play a role in genetic differentiation, i.e. are there apparent limits to dispersal at a European scale? (iv) Can temporal isolation play a role in the host-related restriction of gene flow? (v) Do the genetically distinct mycoparasites show physiological host specificity or are cross-infections possible? To address these questions, we used microsatellite markers (Harvey 2006) and ITS sequences to investigate the mode of reproduction, population structure and host-related differentiation. In parallel, we conducted field experiments to assess 
Version définitive du manuscrit publié dans / Final version of the manuscript published in : Molecular Ecology, 2011, Article first published online, DOI: 10.1111/j.1365-294X.2011.05007.x. The definitive version is available at www3.interscience.wiley.com.

the degree of physiological host specificity. Our expectation was that, if Ampelomyces strains in APM belonged to a cryptic species isolated from congeneric species only by temporal isolation, we would find high genetic differentiation between APM and nonAPM strains, and evidence of recombination between APM strains, but no evidence of mycohost physiological specialization, in the genus Ampelomyces.

\section{Materials and methods}

\section{Ampelomyces strains}

Eighty-nine Ampelomyces strains, isolated from all over the world, were obtained from previous studies (Falk et al. 1995; Kiss \& Nakasone 1998; Sullivan \& White 2000; Szentiványi et al. 2005; Liang et al. 2007), and 645 strains were newly isolated in this work (Data S1, Supporting information). Of these, 261 strains were isolated from APM, some isolated from new collections from the same apple trees from collection sites in Hungary and the United Kingdom that had been sampled for a previous study (Szentiványi et al. 2005). We isolated 264 strains from a common powdery mildew species, Arthrocladiella mougeotii, infecting Lycium halimifolium, and 120 strains from many other species of the Erysiphales across Europe. During field surveys, we have always searched for powdery mildew infections on every plant species present in the surveyed areas, from early spring until late autumn, and isolated Ampelomyces mycoparasites whenever these were found in any powdery mildew species detected in the field. Powdery mildew-infected leaves from which the Ampelomyces strains were isolated were pressed, dried and stored as herbarium materials to be re-examined using light microscopy if necessary.

Over the course of the field experiments outlined below, we repeatedly isolated Ampelomyces mycoparasites from powdery mildew-infected apple, tobacco and cucumber leaves. These leaves were also stored as herbarium materials and used to assess the intensity of mycoparasitism as described below.

\section{Apple leaf samples}

Additional powdery mildew-infected apple leaves carrying Ampelomyces mycoparasites were collected from apple trees across Europe. These were dried, stored and their DNA extracted as described below, without isolating the Ampelomyces in culture. The presence of Ampelomyces pycnidia in the powdery mildew mycelia covering these leaves was confirmed under a dissecting microscope before their storage. This yielded 353 apple leaf samples (Data S1, Supporting information) for which Ampelomyces microsatellite profiles were analysed.

DNA extraction and sequencing of the rDNA ITS region

Total genomic DNA was extracted from 10 to $15 \mathrm{mg}$ freeze-dried mycelium of each Ampelomyces strain and from 5 to $10 \mathrm{mg}$ dried apple leaf sample containing Ampelomyces pycnidia using a DNeasy Plant Mini Kit (Qiagen). DNA extracted from cultivated strains was used to determine both the rDNA ITS sequence and the microsatellite profiles, while DNA obtained from apple leaf samples was used in the microsatellite work only. Polymerase chain reaction (PCR) amplification and sequencing of both strands of the rDNA ITS region were carried out as reported in Szentiványi et al. (2005). The sequences were compiled from electropherograms using PREGAP4 and GAP4 (Staden et al. 2000) and edited using PROSEQ 2.9 (Filatov 2002).

Phylogenetic analysis based on ITS sequences

Multiple alignments of homologous ITS sequences obtained from GenBank were made using Multalin (Corpet 1988). The alignments were checked and manually edited with PROSEQ 2.9 (Filatov 2002) and deposited in TreeBASE (Study ID: S11058). For inferring phylogenies, maximum parsimony (MP) analysis was carried out using the PAUP* 4.0b10 
Version définitive du manuscrit publié dans / Final version of the manuscript published in : Molecular Ecology, 2011, Article first published online, DOI: 10.1111/j.1365-294X.2011.05007.x. The definitive version is available at www3.interscience.wiley.com.

program package (Swofford 2003). Gaps in the alignment were treated as a fifth character, and all characters had equal weight. The other parameters were the default set of the PAUP* with 'MULTREES' on. The statistical supports of the branches of the inferred trees were tested by MP bootstrap analyses with 100 and 1000 replicates using heuristic and fastheuristic searches, respectively. Phylogenetic trees were visualized and edited by Tree Explorer of the MEGA 4.0 program (Tamura et al. 2007) and a text editor.

Permutation test based on ITS sequence data

We assessed whether the particular Ampelomyces ITS haplotypes were associated with particular mycohost species using a permutation test. Four ITS haplotypes were defined each corresponding to a clade recognized in the phylogenetic analysis (Fig. S2, Supporting information). We constructed a two-way contingency table of the four ITS haplotypes crossed with mycohost species, retaining only those from which at least five Ampelomyces strains were isolated. From this table of observed data, we calculated the equivalent of a contingency Chi-square as the sum of the standardized squared deviations from the expected contingency value for each cell [(Observed)Expected) ${ }^{2}$ Expected]. However, because many expected values were $<5$ and several even were $<1$, this statistic is inflated and should not be tested for significance against a Chi-square distribution. We therefore generated an appropriate theoretical distribution by permutation. We generated 999 random assignments of Ampelomyces haplotypes over mycohost species, respecting row and column totals, and calculated the sum of the standardized squared deviations from the expected contingency value for each random table. We compared the value from our observed data set to this distribution to generate the probability that our observed matrix could have arisen by chance associations among strains belonging to the various ITS haplotypes and the mycohost species they parasitized. The more extreme our observed value compared with this distribution, the less probable it is that the associations are formed by chance, indicating a specificity between ITS haplotypes and mycohost species.

Development of ITS-specific primers for the APM strains

Based on the identity of the ITS sequences of all the Ampelomyces strains isolated from APM, an ITS-specific primer (5'-TGAGTCCAGAGGCATAG-3') was designed for this ITS haplotype using the alignment produced for the phylogenetic analyses described above. This primer used in combination with primer ITS1-F (Gardes \& Bruns 1993) was tested on all the 261 APM strains and $>100$ other Ampelomyces strains. The PCR protocol was identical to the one described in Szentiványi et al. (2005) except that the primer annealing temperature was 60 ${ }^{\circ} \mathrm{C}$ instead of $52{ }^{\circ} \mathrm{C}$.

\section{Microsatellite genotyping}

We used five polymorphic microsatellite markers (designated AQmalus3, AQmalus4, AQmalus8, AQmalus10 and AQmalus11), developed by Harvey (2006), for genotyping Ampelomyces isolated from APM. PCR amplifications and allele detections were first carried out in a subset of 50 APM strains using radioactive labelling, i.e. forward primers end-labelled with $\left[c^{33} \mathrm{P}\right]-\mathrm{ATP}$, as described in Harvey (2006). Subsequent micro- satellite genotyping included all the 261 newly isolated APM strains, 353 apple leaf samples, and 38 of the 40 APM strains isolated earlier (two of these, B24 and B55, having been lost after the ITS work) as well as a total of 404 other Ampelomyces strains from our culture collection. These were run using fluorescent labelling as described by Giraud (2004).

Analyses of microsatellite data

We analysed the microsatellite genotypes of 652 APM isolates, consisting of 299 strains and 353 apple leaf samples, obtained from 25 localities in Europe (Fig. 1). Genetic diversity was characterized by the allelic richness (mean number of allele per locus, A) and the expected 
Version définitive du manuscrit publié dans / Final version of the manuscript published in : Molecular Ecology, 2011, Article first published online, DOI: 10.1111/j.1365-294X.2011.05007.x. The definitive version is available at www3.interscience.wiley.com.

heterozygosity, HE. Expected heterozygosity can be used even in haploid species such as Ampelomyces as a measure of genetic diversity: HE is computed based on allelic frequencies and under Hardy-Weinberg assumptions as if the species were diploid; HE is higher with more alleles of more similar frequencies. We assessed whether random sexual reproduction occurred by estimating the index of multilocus linkage disequilibrium (rD) corrected for population structure implemented in MULTILOCUS 2.1 (Agapow \& Burt 2001). Departure from the null hypothesis (no linkage disequilibrium; $r D=0$ ) was assessed by permuting alleles between individuals independently for each locus (1000 permutations) using MULTILOCUS 2.1 program (Agapow \& Burt 2001). We also used the phylogenetic test from Burt et al. (1996) for linkage disequilibrium that compares the length of the most parsimonious tree fitted to the observed data set with that fitted to randomized data sets. Deviation from panmixia should significantly shorten tree lengths. We used MULTILOCUS 2.1 (Agapow \& Burt 2001) to generate the observed and randomized data sets for tree construction in PAUP* (Swofford 2003). Footprints of recombination were sought using the software SplitsTree4 (Huson \& Bryant 2006), which reconstructs trees where reticulation between haplotypes is allowed and indicates recombination. We used the Chord distance (Cavalli-Sforza \& Edwards 1967) on the 240 multilocus genotypes (MLGs) indentified in the APM strains based on microsatellite alleles. We also ran the software eBURST V3 (Feil et al. 2004; Spratt et al. 2004) on microsatellite genotypes of the APM strains which draws diagrams linking haplotypes; recombination usually leads to a single large straggly eBURST group (Turner et al. 2007).

Spatial genetic structure (SGS) was analysed using autocorrelograms (Vekemans \& Hardy 2004). We used the kinship coefficient $\left(\mathrm{F}_{\mathrm{ij}}\right)$ (Loiselle et al. 1995), at various spatial scales, as a means of measuring the relatedness between each pair of individuals. For haploid species like Ampelomyces, $\mathrm{F}_{\mathrm{ij}}$ is equivalent to Moran's index (I), the classical measure of autocorrelation (Legendre \& Legendre 1998). Maximum geographical distance between samples was 1871 $\mathrm{km}$. We defined five distance classes $(0-100,101-500,501-1000,1001-1500$ and 1501-2000 $\mathrm{km}$ ) and tested whether the observed values of $F_{i j}$ within each distance classes differed significantly from 0 (random structure) by using 10000 permutations of spatial locations in the program SPAGeDI 1.2 (Hardy \& Vekemans 2002). Furthermore, assuming gene dispersal in two spatial dimensions, SGS was quantified with the Sp statistic estimated as $) \mathrm{b} /(1) \mathrm{F} 1)$, with b the slope of the regression of ${ }_{\mathrm{Fij}}$ on the logarithm of geographical distance separating the pairs of isolates, and F1, the mean kinship coefficient of the first distance class (Vekemans \& Hardy 2004). 
Version définitive du manuscrit publié dans / Final version of the manuscript published in : Molecular Ecology, 2011, Article first published online, DOI: 10.1111/j.1365-294X.2011.05007.x. The definitive version is available at www3.interscience.wiley.com.

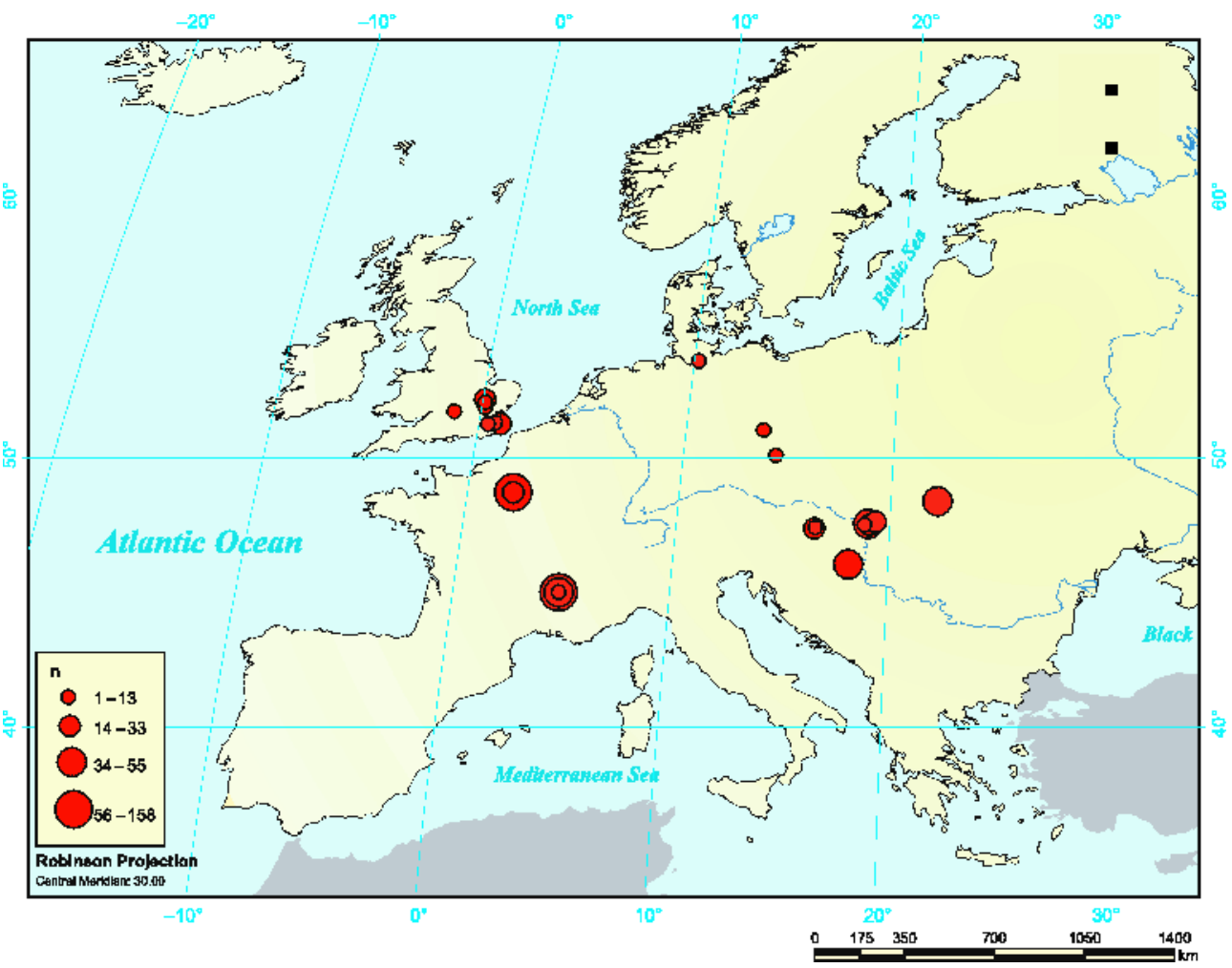

Fig. 1 Distribution of sample sites from which Ampelomyces strains were repeatedly isolated from apple powdery mildew (APM, Podosphaera leucotricha) in spring from 1995 to 2008. The number of strains obtained in different places is also indicated on the map. See also Data S1 (Supporting information).

We further conducted a principal component analysis (PCA) and a spatial PCA using ADEGENET package (Jombart 2008) and ADE4 package (Chessel et al. 2004) implemented in the R-environment ( $\mathrm{R}$ Development Core Team 2010) to analyse the genetic structure of Ampelomyces from APM using microsatellite data. This approach makes no assumptions regarding a population model, nor does it assign individuals to discrete subpopulations. Rather, sPCA ordinates genotypes along a continuum of relatedness taking into account both the genetic variance between individuals and its spatial autocorrelation. We tested the significance of the global and local scores with the Monte Carlo tests implemented in ADEgenet.

Interspecific transmission of APM- and non-APM Ampelomyces under natural field conditions Transmission of APM Ampelomyces to other powdery mildew species in spring. In April-May 2005, 2006, 2008 and 2009, we tested for transmission of Ampelomyces from APM to G. orontii on tobacco and Podosphaera xanthii on cucumber (Fig. 2). Ten potted tobacco (Nicotiana tabacum) plants, cv. Xanthi, with 4-6 fully expanded leaves artificially infected with powdery mildew (G. orontii) in the greenhouse, and 10 potted cucumber (Cucumis sativus) plants, cv. Rajnai Fu“rto"s, with 2-4 fully expanded leaves artificially infected with powdery mildew (P. xanthii) in the greenhouse, were hung on two apple (Malus domestica) trees, cv. Jonathan, to serve as 'traps' for Ampelomyces mycoparasites naturally occurring in APM. This was done at two localities about $20 \mathrm{~km}$ apart. It was known that APM on those trees was naturally parasitized by Ampelomyces by inspection under a dissecting microscope at the beginning of the experiment. Two weeks later, all the exposed tobacco and cucumber plants were collected from both sites, taken to the laboratory and their leaves were examined under a dissecting microscope for the presence of intracellular pycnidia of Ampelomyces in the powdery mildew mycelia. When found, the mycoparasites were isolated and genotyped as described above. At the same time, we also isolated and genotyped Ampelomyces mycoparasites from APM at both sites. 
Version définitive du manuscrit publié dans / Final version of the manuscript published in : Molecular Ecology, 2011, Article first published online, DOI: 10.1111/j.1365-294X.2011.05007.x. The definitive version is available at www3.interscience.wiley.com.

Transmission of non-APM Ampelomyces to P. xanthii and G. orontii in autumn. In midSeptember 2007, 2008 and 2009, we exposed these same two 'trap' powdery mildew species in the same way to Ampelomyces parasitizing A. mougeotii on L. halimifolium at two sites, $10 \mathrm{~km}$ apart (Fig. 2). Arthrocladiella mougeotii, a widespread powdery mildew species that infects $L$. halimifolium wherever this solanaceous plant occurs, is heavily parasitized by Ampelomyces in autumn in the field (Kiss 1998, 2008). The presence of Ampelomyces mycoparasites in the mycelium of A. mougeotii on Lycium leaves was previously confirmed under a dissecting microscope. After a 2-week exposure, we collected and analysed all the tobacco and cucumber plants from both sites as above, as well as isolating and sequencing the ITS of the Ampelomyces mycoparasites from $A$. mougeotii at both sites.

Transmission of APM- and non-APM Ampelomyces to APM in autumn and their overwintering on apple trees. Although APM usually sporulates in spring, under some conditions, it can also sporulate in autumn (Holb 2005) when many other powdery mildews, some parasitized by Ampelomyces, are active. Therefore, we exposed autumn-sporulating APM to airborne Ampelomyces inocula present in the environment to determine whether it is susceptible to parasitism by Ampelomyces, either from rare, autumn-sporulating APM, provided by us experimentally or other powdery mildew species actively sporulating on their host plants (Fig. 3). We further tested whether Ampelomyces contracted by APM in autumn on our experimental apple plants could overwinter on apples to infect the APM colonies next spring.

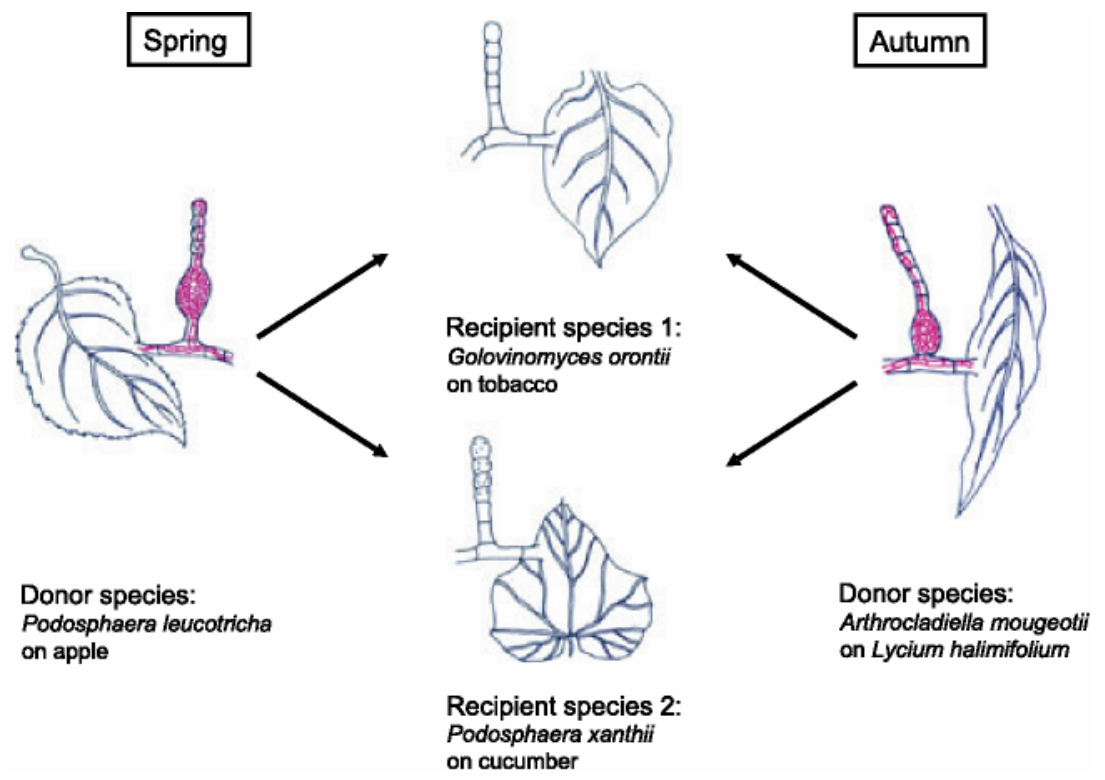

Fig. 2 Outline of the field experiments testing transmission of Ampelomyces strains from apple powdery mildew (APM, Podosphaera leucotricha) in spring and from Arthrocladiella mugeotii in autumn to two 'trap' mycohost species, Golovinomyces orontii infecting tobacco and Podosphaera xanthii infecting cucumber. Powdery mildew is drawn in black while Ampelomyces is in red.

To produce young apple plants with freshly sporulating APM colonies in autumn, 30 apple seedlings, cv. Jonathan, were grown from seed in spring 2005 in a spore-proof growth chamber to protect them from air- borne APM infections. On the 19th of August 2005, 15 healthy seedlings were removed from the growth chamber and infected with APM in the greenhouse. To ensure a regular supply of fresh spores for this inoculation treatment, we grew susceptible (cv. Jonathan) apple seedlings throughout the summer, reinoculating batches of 10 of them whenever necessary. The remaining 15 mildew-free seedlings were kept in the chamber until November and were used as control plants in this experiment. The 15 seedlings, infected on 19 August 2005, with freshly sporulating APM colonies on their leaves, were placed outside the greenhouse on the 1st of September 2005 next to 20 potted, 3-year-old 
Version définitive du manuscrit publié dans / Final version of the manuscript published in : Molecular Ecology, 2011, Article first published online, DOI: 10.1111/j.1365-294X.2011.05007.x. The definitive version is available at www3.interscience.wiley.com.

apple trees, cv. Jonathan, with sporulating APM known, by isolation and genotyping, to be infected with an APM haplotype of Ampelomyces. The sporulation of APM on these 3-year-old apples was also maintained artificially throughout the summer. The sporulation of APM in late summer and early autumn can sometimes be detected in the field (Holb 2005), especially on young shoots, and in this case, this was stimulated by pruning a part of the older shoots of these 3-year-old trees. Thus, the sporulating APM mycelia on the 15 newly infected seedlings were exposed to an APM strain of Ampelomyces present on the 3-year-old apple trees but also to any other airborne Ampelomyces inoculum coming from powdery mildew species that naturally sporulated in the environment in September-October 2005 on dandelion, horse chestnut, Norway maple, pedunculate oak and a number of other plant species (Fig. 3).

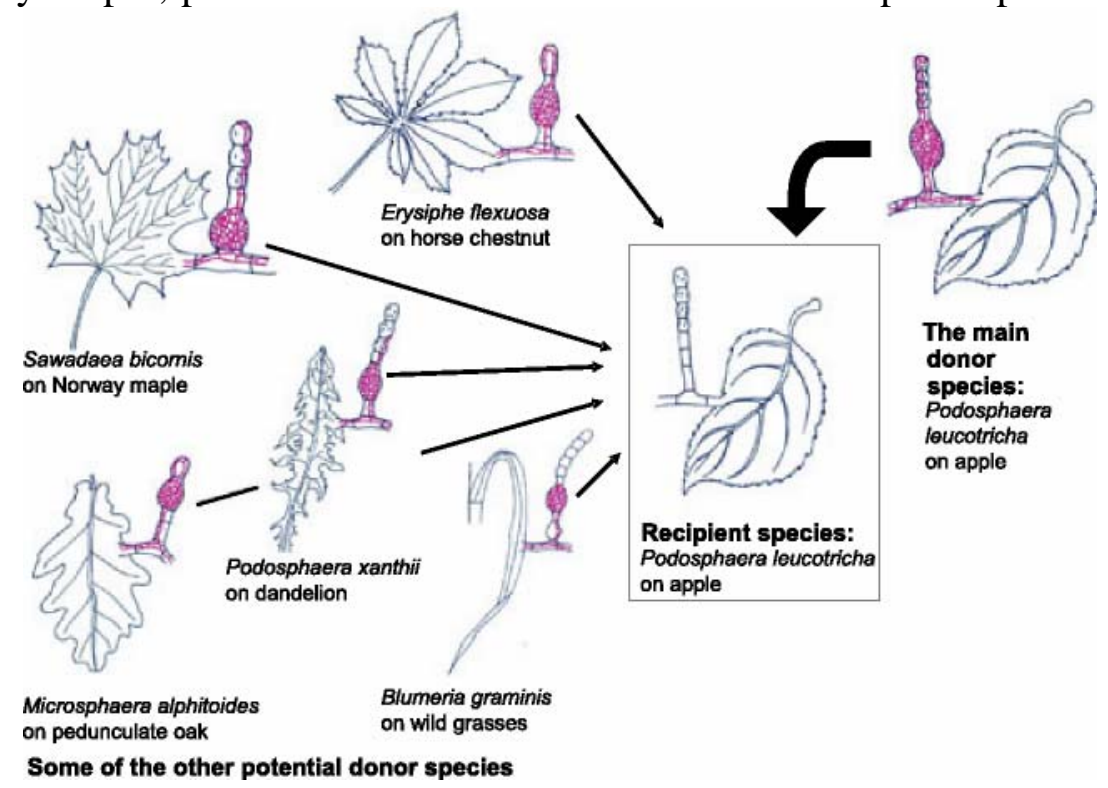

Fig. 3 Outline of the field experiment testing transmission of Ampelomyces strains to apple powdery mildew (APM, Podosphaera leucotricha) from various mycohost species, including APM parasitized by a known Ampelomyces strain, in autumn. Powdery mildew is drawn in black while Ampelomyces is in red.

After leaf fall in November 2005, the 15 potted seedlings infected with APM and exposed to Ampelomyces sources since the 1st of September, as well as the 15 healthy control seedlings kept mildew-free in isolation, all now 50-75 cm tall, were overwintered outside the greenhouse. APM overwinters in apple buds and Ampelomyces mycoparasites overwinter in or around these buds (Szentiványi \& Kiss 2003). In February 2006, to provoke precocious bud burst, the 30 potted apple plants were placed in a heated, 10-15 oC greenhouse with natural plus $4 \mathrm{~h}$ of artificial illumination. The development of leaves and APM colonies on the shoots were examined daily, and the presence of Ampelomyces in APM mycelia was examined under a dissecting microscope. When found, mycoparasites were isolated and genotyped for ITS and microsatellites.

\section{Assessment of mycoparasitic activity of different Ampelomyces strains in different powdery mildew species}

To determine whether Ampelomyces haplotypes differed in their ability to colonize and sporulate in different host powdery mildew fungi, we counted pycnidia of the different Ampelomyces genotypes that had infected our experimental P. xanthii or G. orontii on potted cucumber and tobacco plants, respectively. We counted all pycnidia in two $1.5-\mathrm{mm}^{2}$ surface area fields on one leaf from each of three to five potted cucumber and tobacco plants from the experiments, using the dried leaves from which strains had been isolated to determine their genotypes. Counts were performed only in areas of mature pycnidia, characterized by 
Version définitive du manuscrit publié dans / Final version of the manuscript published in : Molecular Ecology, 2011, Article first published online, DOI: 10.1111/j.1365-294X.2011.05007.x. The definitive version is available at www3.interscience.wiley.com.

a dark brown colour. These powdery mildew fungi were infected with either the APM haplotype or with Ampelomyces from clade 1 or 3 (Fig. 4), originating from A. mougeotii on Lycium or several other powdery mildew species infecting various host plants. We tested the repeatability of the two measures from individual leaves, which was high ( $\mathrm{ri}=0.96$, $\mathrm{F} 45,46=24.20, \mathrm{P}<0.0001)$ and then used their means to test whether pycnidial density differed between the host powdery mildew fungi or by Ampelomyces haplotype within the two host fungi, using a nested ANOVA.

Fig. 4. A simplified version of one of the six most parsimonious trees inferred from nrDNA internal transcribed spacer sequences of 184 Ampelomyces strains with PAUP* 4.0b10 pro- gram package (Swofford 2003). Strains shown as red squares were isolated from Podosphaera leucotricha infecting apple, those in green from Arthrocladiella mougeotii infecting Lycium halimifolium and strains shown in blue from Podosphaera pannosa infecting rose. Strains isolated from all the other powdery mildew species are designated as grey squares. Branches with $>75 \%$ bootstrap support are highlighted with thicker lines. Bar $=10$ changes. See Fig. S2 (Supporting information) for details.

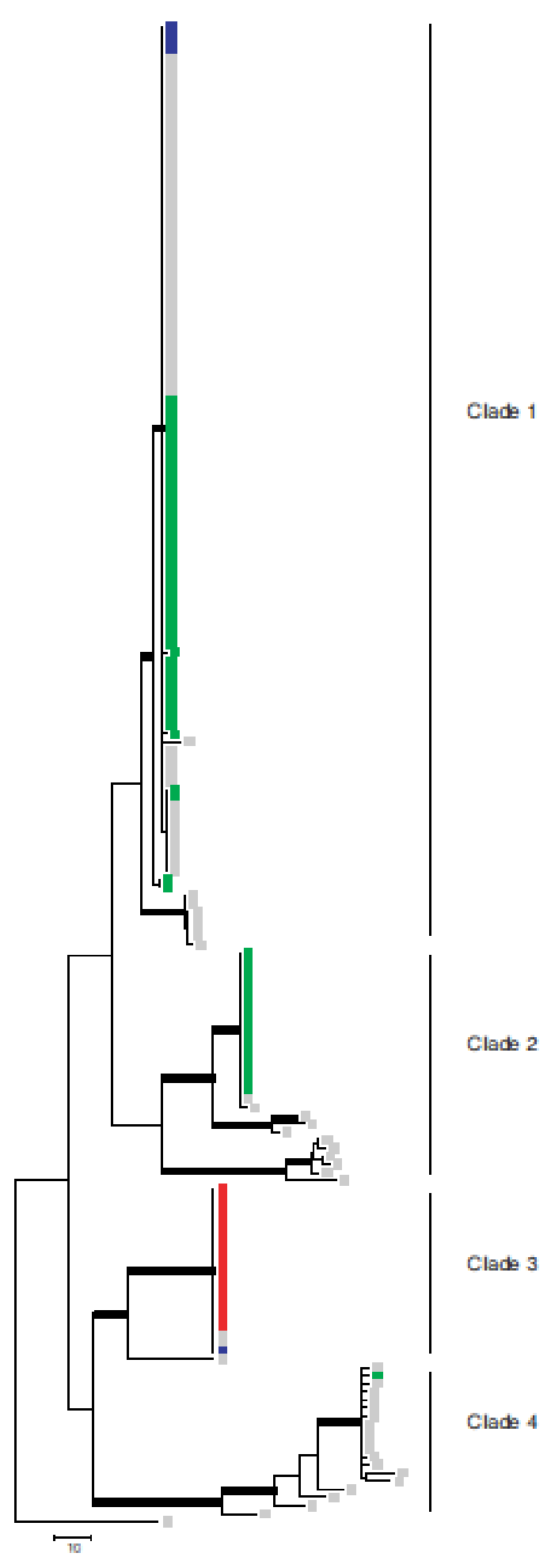


Version définitive du manuscrit publié dans / Final version of the manuscript published in : Molecular Ecology, 2011, Article first published online, DOI: 10.1111/j.1365-294X.2011.05007.x. The definitive version is available at www3.interscience.wiley.com.

\section{Results}

APM Ampelomyces strains are genetically differentiated from those isolated from other powdery mildew fungi based on ITS sequence and microsatellite markers

All the 301 APM Ampelomyces strains studied in this work, including 40 strains from a previous study, isolated between 1995 and 2002 (Szentiványi et al. 2005), and 261 newly obtained ones isolated in 2008 across Europe, carried the same ITS haplotype identified in that previous work different from almost all the ITS haplotypes present in Ampelomyces strains coming from other powdery mildew hosts. This was shown by amplifications with ITS primers specific of the APM Ampelomyces haplotype, developed in this work, and sequencing the PCR products in >100 APM strains. All these ITS sequences were identical; therefore, sequences for only 18 APM strains were included in the phylogenetic analysis to keep the size of the trees within reasonable limits. Only three of 433 Ampelomyces strains isolated from powdery mildew species other than P. leucotricha exhibited ITS sequences identical to those of the APM ITS haplotype (Figs 4 and S2, Supporting information). Two of these three strains, $\mathrm{U} 1$ and GW, were isolated in spring while the exact isolation time of the third one, AqW, is unknown (Data S1, Supporting information).

The five polymorphic microsatellite markers yielded one allele per locus, as expected for single strain isolates of haploid fungi, for all the 652 APM isolates used in this work, consisting of 299 APM strains of the 301 studied, two having been lost, and 353 apple leaf samples (Data S1, Supporting information). Poor amplification was obtained for the 404 non-APM strains from different hosts included in the microsatellite work, with no amplicons for any marker in 235 isolates and only one to three amplifying microsatellite markers in the remaining isolates (data not shown).

\section{APM Ampelomyces strains practice clonal replication and regular recombi nation}

Several lines of evidence suggest the cooccurrence of clonal replication and recombination in APM Ampelomyces. Among the 652 APM isolates genotyped at the 5 micro- satellite loci, we found a mean of 10.2 (min: 5 and max: 21) alleles per locus with a mean genetic diversity (HE) of 0.74 $( \pm 0.11)$. We identified 240 MLGs, 24 of which were sampled at least twice at the same or different localities. Applying a clone-correction by keeping a single copy of each MLG per locality led to a data set composed of 274 genotypes.

Linkage disequilibrium among microsatellite loci, assessed using the multilocus index of association, $\mathrm{r}_{\mathrm{D}}$, was -0.16 for the complete data set and 0.044 for the clone-corrected data set. Both values were significantly different from $0(\mathrm{P}<0.001)$. The most parsimonious tree for the microsatellite data was much shorter (265 mutational steps) than those obtained from randomized data sets simulating free recombination among loci (325 and 500 steps for clonecorrected and complete data sets,respectively, Fig. S3, Supporting information). Both analyses thus indicated that clonality influenced allele associations (Burt et al. 1996).

However, the tree of the MLGs identified in the APM strains, built using SplitsTree4, showed reticulations (Fig. 5), indicating recombination among APM strains. The eBURST diagram (Fig. S4, Supporting information) showed a single large straggly group with all MLGs linked together, also consistent with recombination occurring in populations with few alleles (Turner et al. 2007). Recombination indeed biases the eBURST algorithm, rendering the eBURST diagram unreliable for inferring the relationship among MLGs, especially the connection among radial groups. However, the obtained pattern is strongly indicative of regular recombination and low mutation rates (Turner et al. 2007). 
Version définitive du manuscrit publié dans / Final version of the manuscript published in : Molecular Ecology, 2011, Article first published online, DOI: 10.1111/j.1365-294X.2011.05007.x. The definitive version is available at www3.interscience.wiley.com.

Geographical structure and long-distance migration of the APM Ampelomyces isolates

Spatial structure analyses suggested large-scale dispersal and weak geographical pattern. Identical MLGs were found at sites separated by up to $1618 \mathrm{~km}$, suggesting that dispersal over long distances is possible. Spatial auto-correlograms revealed a kinship coefficient $\left(\mathrm{F}_{\mathrm{ij}}\right)$ significantly different from 0 only for the first distance class from 0 to $100 \mathrm{~km}(\mathrm{~F} 1=0.025, \mathrm{P}=$ 0.001). The regression slope (b) between Fi1 and the logarithm of geographical distance separating pairs of isolates was also significantly different from $0(\mathrm{~b}=) 0.016, \mathrm{P}<$ 0.001). The level of genetic structure quantified using the Sp statistics (Vekemans \& Hardy 2004) was significant ( $\mathrm{Sp}=0.016, \mathrm{P}<0.001$ ), but rather weak, implying a large extent of large-scale dispersal.

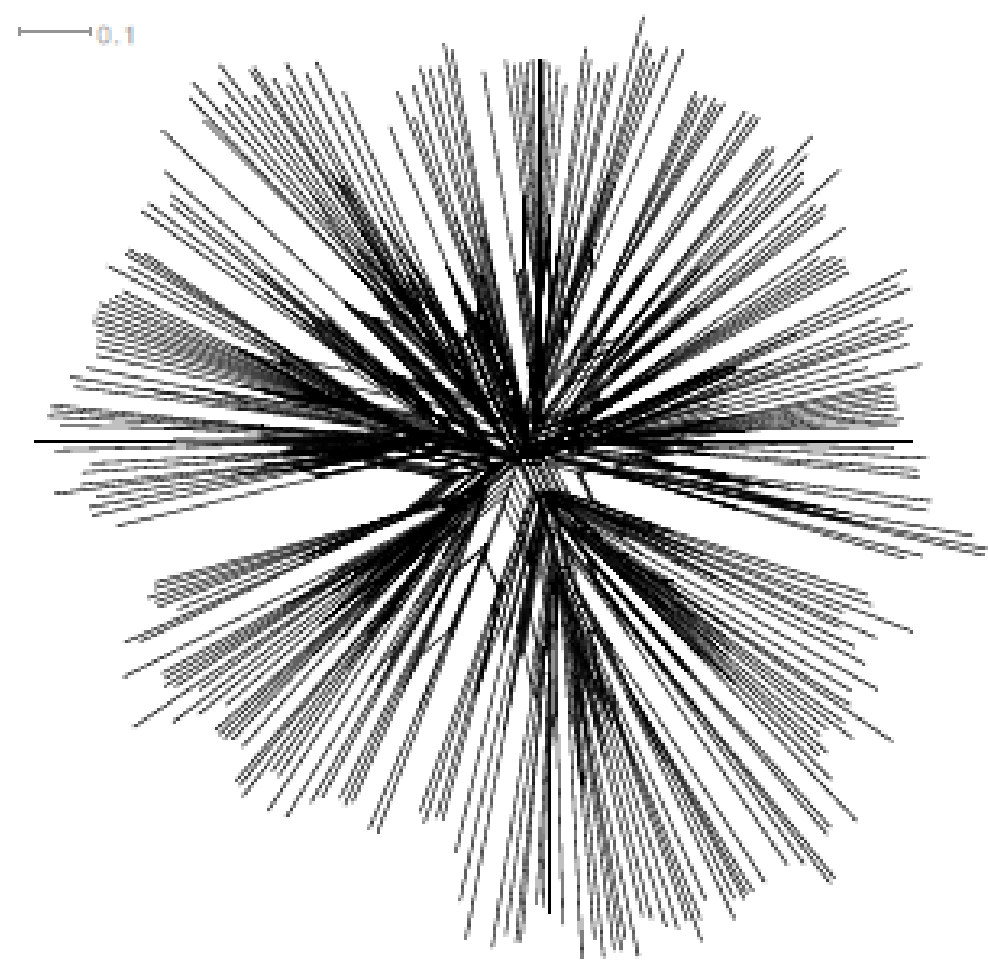

Fig. 5 SplitsTree4 diagram for the microsatellite multilocus genotypes identified in Ampelomyces strains isolated from apple powdery mildew. Reticulation indicates the occurrence of recombination.

This weak geographical pattern was confirmed by principal components (PCs) analysis of microsatellite data (Fig. 6). The first two PCs for APM Ampelomyces strains explained respectively $14 \%$ and $12 \%$ of the total variance, but failed to group MLGs according to their geographical locations. A spatially auto-correlated genetic variance component approach, however, revealed that geographically closer strains were genetically more similar than more distant ones, despite overlap among countries of origin, with the first two spatial PCs (sPCs) showing a significant proportion of positively auto-correlated genetic variance (Global Monte Carlo test, $10^{5}$ permutations, $\mathrm{P}<1 \cdot 10^{15}$ for both sPCs).

\section{No indication of strict host specificity based on ITS sequences of non-APM Ampelomyces strains}

In contrast to the pattern observed in APM Ampelomyces strains, the ITS sequences of Ampelomyces mycoparasites isolated from other powdery mildew species were highly variable and did not reveal clear associations with a single particular mycohost or host plant species (Fig. 4 and S2, Supporting information). Ampelomyces strains with identical ITS sequences were found in 
Version définitive du manuscrit publié dans / Final version of the manuscript published in : Molecular Ecology, 2011, Article first published online, DOI: 10.1111/j.1365-294X.2011.05007.x. The definitive version is available at www3.interscience.wiley.com.

different powdery mildew species, and different ITS haplotypes were isolated from the same powdery mildew species infecting the same host plant species, even in the same area. For example, the ITS sequences were markedly different in Ampelomyces strains isolated from P. pannosa infecting Rosa, four of them belonging to clade 1 and the fifth to clade 3 (see strains in blue colour in Fig. S2, Supporting information). Similarly, three strains from E. sordida belonged to clade 1 and the fourth one to clade 2 (see strains in brown colour in Fig. S2, Supporting information). Nonetheless, there was an overall significant association of Ampelomyces ITS haplotypes with mycohost species $(\mathrm{P}=0.001$ from the permutation test) that was evident for mycohosts other than just APM. Ampelomyces strains belonging to clade 4 were found almost exclusively in $P$. fusca and $P$. xanthii, and those from clades 1 and 2 were overrepresented in A. mougeotii.

The only powdery mildew species other than APM from which we had a large number of Ampelomyces strains, a total of 267, was A. mougeotii infecting L. halimifolium bushes. This powdery mildew fungus represents a common species that becomes widespread in our sampling areas starting from August to September (Kiss 1998), in contrast to APM that starts its life cycle in early spring and causes epidemics mostly before summer. The ITS sequences were determined in 65 strains of the 267, and there were considerable differences among them (see strains in green in Fig. 4 and S2, Supporting information). All but two of these strains were isolated in Hungary, thus in a relatively small geographical area, from 1990 to 2008 (Data S1, Supporting information). In some cases, different ITS haplotypes were detected even on the same $L$. halimifolium bush in Hungary, and the two Chinese strains from A. mougeotii, JY3 and HMLAC202, also belonged to different clades (Fig. S2, Supporting information).

Reciprocally, Ampelomyces strains with identical ITS sequences were found in different powdery mildew species. For example, 91 strains isolated from different species of powdery mildew fungi belonging to six genera, Podosphaera, Erysiphe, Golovinomyces, Arthrocladiella, Phyllactinia and Sawadaea, and collected from 21 host plant genera, all exhibited identical ITS sequences and grouped into clade 1 together with a number of other strains with ITS sequences that differed in one or a few nucleotides from each other (Fig. S2, Supporting information). The 91 strains carrying identical ITS sequences were isolated in different European countries, China, Israel, South Africa and the USA; thus, there was no indication of any association with the localities of origin. To ensure that this analysis was carried out in the most conservative way, gaps in the alignment of the ITS sequences were treated as the fifth character, and powdery mildew fungi infecting different host plant genera were treated as different taxa regardless of the binomials used for these plant pathogens. This latter criterion was necessary because species delimitation is not always the most accurate within the Erysiphales, and some binomials, such as P. xanthii, P. fusca and G. cichoracearum, mentioned in this work, represent species complexes that include cryptic species with different host plant ranges (e.g., Glawe 2008).

Unfortunately, collection date, and hence season, is unknown for most of the strains used in previous studies. For those collected for this study, the 383 non-APM strains that exhibited ITS sequences different from the APM haplotype were collected in September-October across Europe. In spring, we found non-APM strains in the field only once, in southern France, where 25 strains were isolated from five powdery mildew species (Data S1, Supporting information). In contrast to APM, all these five mycohost species are known to actively sporulate and spread on their respective host plants during the whole vegetation period. One non-APM strain (GW) of those 25 isolated in spring exhibited an ITS sequence identical to that of the APM haplotype while the rest of the strains fell into clade 1. 
Version définitive du manuscrit publié dans / Final version of the manuscript published in : Molecular Ecology, 2011, Article first published online, DOI: 10.1111/j.1365-294X.2011.05007.x. The definitive version is available at www3.interscience.wiley.com.

APM and non-APM Ampelomyces strains are easily transmitted to different mycohost species under natural field conditions

The high genetic differentiation of Ampelomyces strains found in APM from those isolated from other powdery mildew fungi, despite long-distance dispersal ability and recombination, could result from physiological host specificity. We tested whether Ampelomyces strains naturally parasitizing APM in spring and those parasitizing other powdery mildew species on other host plant species were able to infect alternative powdery mildew species by experimentally providing potential hosts near infected powdery mildew sources naturally parasitized by Ampelomyces.

Spring APM Ampelomyces strains can infect other powdery mildews. When potted cucumber and tobacco plants experimentally infected with their respective powdery mildew species, $P$. xanthii and G. orontii, were suspended, after bud burst in spring, on apple trees known to harbour Ampelomyces-infected APM (Fig. 2), these powdery mildew species contracted Ampelomyces infections. Successful Ampelomyces infections of the cucumber powdery mildew were found in 3 of 4 years and of tobacco powdery mildew all 4 years of this study. The ITS sequences and microsatellite profiles of the 27 Ampelomyces strains isolated from these two powdery mildew species after 2 weeks exposure on infected apple trees all corresponded to the APM haplotypes of Ampelomyces, as did the strains isolated from the apple trees. This confirmed that the mycoparasites that overwintered on apple trees, present in the primary APM colonies soon after bud break in spring (Szentiványi \& Kiss 2003), could easily spread to other powdery mildew species provided these were available in their close vicinities at that time.

Ampelomyces strains infecting the powdery mildew species Arthrocladiella mougeotii in autumn can infect other powdery mildew species. We obtained successful infection of these same two powdery mildew species on cucumber and tobacco when placed near the plant L. halimifolium infected with its powdery mildew species, A. mougeotii, in autumn, when this latter harboured Ampelomyces (Fig. 2). The mycoparasites appeared in the mycelia of both cucumber and tobacco powdery mildew 2 weeks after exposure in 2007 and of tobacco powdery mildew only in 2008 and 2009 (the experimental cucumber plants died prematurely in these years). The ITS haplotypes of the 22 strains isolated from the cucumber or tobacco powdery mildews, and one strain from each $L$. halimifolium bush, all belonged to either clade 1 or 3 (Fig. 4). Thus, the two powdery mildew species $P$. xanthii and G. orontii were successfully parasitized by both APM strains of Ampelomyces in spring and two different ITS haplotypes of Ampelomyces coming from A. mougeotii naturally infecting L. halimifolium in autumn.

APM can be infected by APM and non-APM Ampelomyces strains in autumn. Although APM usually sporulates only in spring, when manipulated to sporulate in autumn, it was susceptible to infection by both APM Ampelomyces strains and Ampelomyces strains that infect autumn-sporulating powdery mildew species. Sporulating APM on 15 potted apple seedlings that were placed outdoors in September 2005 showed Ampelomyces infection 3 weeks after exposure. The apple seedlings were exposed to APM Ampelomyces from 3-year-old potted apple trees bearing sporulating APM known to be infected with the APM haplotype of Ampelomyces and to non-APM Ampelomyces from several other plant species in the vicinity (Fig. 3). After being overwintered outdoors and having bud burst forced in the greenhouse before any natural powdery mildew and Ampelomyces inoculum appeared in the environment, APM developed on all 15 experimental apple plants, but none of the 15 controls. Ampelomyces mycoparasites were present, i.e. had successfully overwintered and emerged, in APM of five of the 15 experimental plants. Of the 17 Ampelomyces strains isolated from the overwintered APM, 15 were of the APM ITS haplotype and had microsatellite genotypes identical to those of the surrounding infected apple trees, and two had ITS sequences identical to non-APM Ampelomyces strains belonging to clade 1, often found parasitizing A. mougeotii from Lycium halmifolium and several other powdery mildew species (Fig. S2, Supporting information). 
Version définitive du manuscrit publié dans / Final version of the manuscript published in : Molecular Ecology, 2011, Article first published online, DOI: 10.1111/j.1365-294X.2011.05007.x. The definitive version is available at www3.interscience.wiley.com.

Therefore, both non-APM and APM haplotypes of Ampelomyces could infect APM when this species was available in the autumn and overwinter on apple.

Mycoparasitic activity of genetically different Ampelomyces strains in different powdery mildew species. The density of Ampelomyces pycnidia was counted on the leaves of the experimentally exposed cucumber and tobacco plants, each infected with its powdery mildew fungus. Ampelomyces density was about twice as great in $G$. orontii on tobacco $(5227 \pm 93.3$ pycnidia $/ \mathrm{cm}^{2}$ mycelium) as in $P$. xanthii on cucumber (2714.28 \pm 115.4 pycnidia/cm ${ }^{2}$ mycelium), $\mathrm{F} 1,40=299.33(\mathrm{P}<0.0001)$ in both spring and autumn experiments. This directly reflects the difference in density of powdery mildew conidiophores available for intracellular pycnidial production by these mycoparasites. However, we found no significant heterogeneity among Ampelomyces strains on the same 'trap' powdery mildew species $(\mathrm{F} 4,40=1.37, \mathrm{P}=0.26)$ although the strains were genetically diverse coming from APM in spring and A. mougeotii in autumn. This suggests that sporulation density is determined entirely by the powdery mildew host, and the mycoparasitic activity of genetically distinct strains is similar in a given mycohost species. 
Version définitive du manuscrit publié dans / Final version of the manuscript published in : Molecular Ecology, 2011, Article first published online, DOI: 10.1111/j.1365-294X.2011.05007.x. The definitive version is available at www3.interscience.wiley.com.
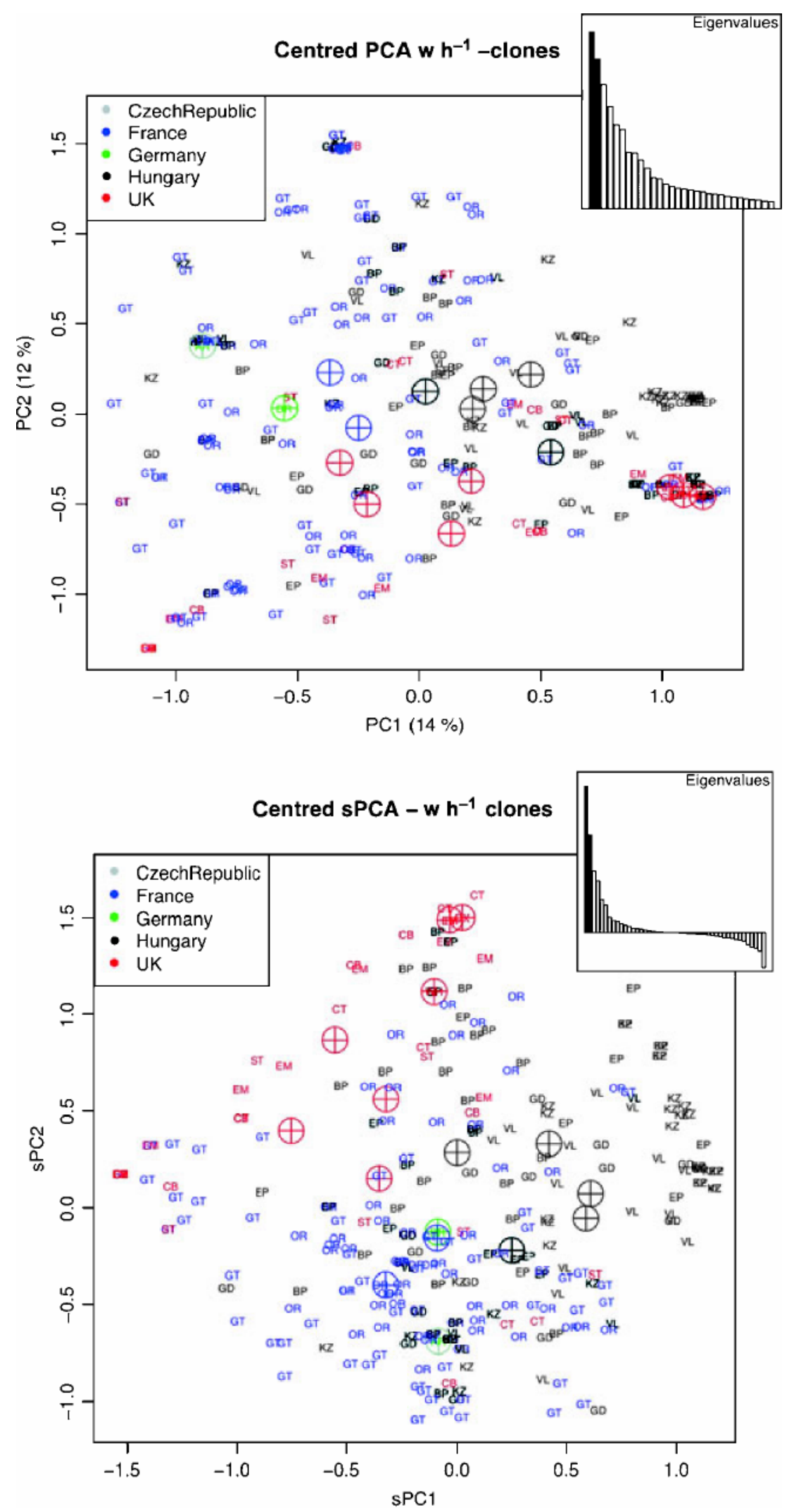

Fig. 6 Centred-PCA (top) and spatial PCA (bottom) on the clone-corrected data set. The eigenvalues are shown in the inserts. The crosses are the locality centroids. The 17 locations ( $\mathrm{n}=274)$ are as follows: AR: Ahrensburg (1); BP: Budapest (32); CB: Cambridge (8); CT: Canterbury (8); DR: Dresden (1); EM: East Malling (9); EP: Eperjeske (23); GD: Gödölló (18); GT: Gotheron (56); KZ: Keszú (27); OR: Orsay (57); OX: Oxford (1); PR: Prague (1); ST: Stansted (6); TY: Teynham (1); VL: Velem (23); WH: Whittlesford (1).

\section{Discussion}


Version définitive du manuscrit publié dans / Final version of the manuscript published in : Molecular Ecology, 2011, Article first published online, DOI: 10.1111/j.1365-294X.2011.05007.x. The definitive version is available at www3.interscience.wiley.com.

Ampelomyces mycoparasites currently belong to a single nominal species, A. quisqualis, considered to be a generalist intracellular parasite of powdery mildews; however, a number of distinct genetic lineages have been recognized (Kiss \& Nakasone 1998; Sullivan \& White 2000; Nischwitz et al. 2005; Szentiványi et al. 2005; Liang et al. 2007; Park et al. 2010). Here, we report that Ampelomyces found in APM caused by P. leucotricha in nature are genetically distinct from Ampelomyces mycoparasites infecting other mycohosts responsible for powdery mildew on other plant species. Indeed, APM Ampelomyces strains all carried one identical ITS haplotype, divergent from ITS haplotypes found in all but three other strains collected from powdery mildew species other than APM. The differentiation in the ITS sequence between APM- and non-APM Ampelomyces corresponds to species-level differences (Seifert et al. 1995; Nilsson et al. 2008). Furthermore, microsatellite markers developed from an APM Ampelomyces strain (Harvey 2006) failed to amplify in most non-APM Ampelomyces strains, as is frequent when microsatellite markers from one fungal species are used for other species (Dutech et al. 2007), because of mutations in the flanking regions. The rare amplifications in non-APM Ampelomyces strains yielded bands with allele sizes different from those carried by APM Ampelomyces strains. Altogether, this suggests that Ampelomyces infecting APM represents a cryptic species, distinct from Ampelomyces species infecting other powdery mildews.

We then attempted to test different hypotheses about the barriers to gene flow allowing the maintenance of the distinct APM Ampelomyces lineage. Analyses using microsatellite markers revealed genetic pattern within APM Ampelomyces strains consistent with frequent asexual reproduction, but also with the occurrence of regular recombination. This suggests that the Ampelomyces strains in APM are not isolated from non-APM Ampelomyces strains by strict asexuality of the former. Physiological host specificity is not strict either in these Ampelomyces mycoparasites as revealed by our field experiments. The powdery mildew species $P$. xanthii on cucumber and $G$. orontii on tobacco became infected with both APM Ampelomyces from P. leucotricha and Ampelomyces strains of two distinct ITS haplotypes often found in A. mougeotii infecting L. halimifolium. We also found that APM could, if exposed while sporulating, become infected by the Ampelomyces normally associated with $A$. mougeotii infecting L. halimifolium and several other powdery mildews. Furthermore, all of these Ampelomyces strains successfully produced large numbers of pycnidia even when infecting a nonhabitual host. Thus, intrinsic physiological barriers to infection are not adequate for explaining the high differentiation between the Ampelomyces mycoparasites of P. leucotricha on apple and the Ampelomyces mycoparasites of other powdery mildew species. Nor can geography explain the strong genetic differentiation between APM and non-APM strains because our genetic analyses revealed frequent long-distance dispersal events. Other mechanisms must exist that prevent both dispersal from APM to other mycohosts, and vice versa, and mating between Ampelomyces strains infecting APM and those found in other mycohosts.

The APM overwinters in apple buds, a particular ecological situation, and it was shown that APM Ampelomyces shares this overwintering site (Szentiványi \& Kiss 2003). It is possible therefore that particular adaptation associated with this particular overwintering behaviour may contribute to genetic isolation between APM- and non-APM Ampelomyces. However, non-APM Ampelomyces were capable of overwintering in apple buds in association with APM in our experiment, suggesting that specific overwintering requirements are also insufficient for explaining the genetic differentiation.

We suggest that genetic isolation between APM- and non-APM Ampelomyces results mainly from temporal isolation. Indeed, the life cycle of APM is mostly completed in spring and early summer while most other powdery mildew species start their life cycle later in the season, causing epidemics mostly in autumn (Szentiványi et al. 2005), thereby isolating the APM Ampelomyces from Ampelomyces of other powdery mildew hosts that cause epidemics in autumn. We did find three exceptions to the APM specificity of the divergent ITS haplotype of 
Version définitive du manuscrit publié dans / Final version of the manuscript published in : Molecular Ecology, 2011, Article first published online, DOI: 10.1111/j.1365-294X.2011.05007.x. The definitive version is available at www3.interscience.wiley.com.

Ampelomyces in our sample. Two of these strains, those for which the date of collection was known, were collected in spring in the vicinity of apple trees infected with APM parasitized by APM strains. Therefore, although this APM ITS haplotype is not entirely restricted to the APM host, it appears to occur predominantly in spring, at least in the sampled European region. Another strain with APM ITS haplotype was reported from China (Liang et al. 2007) and another one from Korea (Park et al. 2010), both from rosaceous host plants.

Non-APM haplotypes of Ampelomyces were also detected, albeit infrequently, in spring in mycohosts other than APM. This means that such haplotypes are also present early in the season and could, in principle, become established in APM. However, it appears that the chances for such events are limited, in part because of the low number of powdery mildew species other than APM that are actively growing and sporulating in spring and the low number of non-APM haplotypes of Ampelomyces detected in these mycohosts. Furthermore, APM becomes dormant after its spring outbreaks, limiting the temporal window available for infection by other Ampelomyces strains. Ampelomyces spread between powdery mildew species that are sporulating over the whole vegetation period appears more likely.

Increasing genetic differentiation with increasing divergence in the seasonal timing of reproduction has been reported in numerous organisms (Hendry \& Day 2005). Models show that increasing phenological divergence can even lead to sympatric speciation (Stamm 1983; Devaux \& Lande 2008). Observations from animal parasites (Théron \& Combes 1995), flowering plants (Savolainen et al. 2006) and plant pathogenic fungi (Van Putten et al. 2007; Montarry et al. 2008, 2009) are also consistent with the idea that temporal isolation can allow ecological differentiation. Here, we provide a compelling case that such a mechanism operates in mycoparasites with wide host ranges whose phenology is largely controlled by the phenology of their mycohosts.

Whether genetic isolation, when it occurs within a restricted geographical area, should be considered sympatric and because of ecological factors or because of allopatry is not a trivial question. A very useful and operational definition of sympatry is provided by Kondrashov \& Mina (1986) who suggested that sympatry requires that only the genotypes and no extrinsic factors control the probability of mating between two individuals. The distinction is important as the former case poses theoretical difficulties to explain differentiation, in contrast to the latter. With this definition, genetic isolation that is initiated and/or maintained because of temporal isolation can be considered sympatric if the timing of reproduction is largely under genetic control. In most plants and animals, there is a genetic component for phenological variation, so genotype directly influences which mating partners are available (Hendry \& Day 2005). If only particular Ampelomyces genotypes are able to exploit APM, which sporulates mainly in spring, then temporal isolation is caused by genotype via its adaptation to a particular host with a particular phenology. In contrast, if temporal isolation is entirely determined by the plant and the powdery mildew phenologies, and any Ampelomyces genotype placed in that particular environment would sporulate and transmit exclusively in spring, the barrier to gene flow would be extrinsic to Ampelomyces, i.e. not caused by its genes, and thereby resemble allopatry (Giraud 2006a,b). Indeed, if speciation were to occur under such a scenario, it would be by gradual divergence of a subset of genotypes in isolation, i.e. a speciation governed by external barriers to gene flow as in allopatry.

We have shown that APM Ampelomyces strains form a distinct clade with a single ITS haplotype and divergent microsatellite loci and alleles from the rest of the Ampelomyces. This is strong evidence that APM Ampelomyces is a cryptic species. The ability for APM Ampelomyces to transmit to other powdery mildew hosts and vice versa suggests that genetic determinants of host use are not strict. Genotype, therefore, does not determine host use ability and as such may suggest that divergence occurred in effective allopatry via temporal isolation, i.e. without selection for ecological divergence. 
Version définitive du manuscrit publié dans / Final version of the manuscript published in : Molecular Ecology, 2011, Article first published online, DOI: 10.1111/j.1365-294X.2011.05007.x. The definitive version is available at www3.interscience.wiley.com.

\section{Acknowledgements}

The authors thank Eva Arpadne Mayer and Odile Jonot for technical assistance. AP acknowledges a fellowship of the French government. This study was supported in part by an EU grant (FP 7-SME-2007-1-222045-BCA_grape) and an INRAHAS collaborative project.

\section{References}

Agapow P-M, Burt A (2001) Indices of multilocus linkage disequilibrium. Molecular Ecology Notes, 1, 101-102.

Berlocher SH, Feder JL (2002) Sympatric speciation in phytophagous insects: moving beyond controversy. Annual Review of Entomology, 47, 773-815.

Burt A, Carter DA, Koenig GL, White TJ, Taylor JW (1996) Molecular markers reveal cryptic sex in the human pathogen Coccidioides immitis. Proceedings of the National Academy of Sciences of the USA, 93, 770-773.

Cavalli-Sforza LL, Edwards AWF (1967) Phylogenetic analysis: models and estimation procedures. American Journal of Human Genetics, 19, 233-257.

Chessel D, Dufour AB, Thiouluose J (2004) The ade4 package - I: one-table methods. R News, 4, 5-10.

Corpet F (1988) Multiple sequence alignment with hierarchical clustering. Nucleic Acids Research, 16, 10881-10890.

Coyne JA, Orr HA (2004) Speciation. Sinauer Associates, Sunderland, MA.

Devaux C, Lande R (2008) Incipient allochronic speciation due to non-selective assortative mating by flowering time, mutation, and genetic drift. Proceedings of the Royal Society of London, Series B, 275, 2723-2732.

Dutech C, Enjalbert J, Fournier E et al. (2007) Challenges of microsatellite isolation in fungi. Fungal Genetics \& Biology, 44, 933-949.

Falk SP, Gadoury DM, Cortesi P, Pearson RC, Seem RC (1995) Parasitism of Uncinula necator ascomata by the mycoparasite Ampelomyces quisqualis. Phytopathology, 85, 794-800.

Feil EJ, Li BC, Aanensen DM, Hanage WP, Spratt BG (2004) eBURST: inferring patterns of evolutionary descent among clusters of related bacterial genotypes from multilocus sequence typing data. Journal of Bacteriology, 186, 1518-1530.

Filatov DA (2002) ProSeq: a software for preparation and evolutionary analysis of DNA sequence data sets. Molecular Ecology Notes, 2, 621-624.

Fisher MC, Hanage WP, de Hoog S et al. (2005) Low effective dispersal of asexual genotypes in heterogeneous landscapes by the endemic pathogen Penicillium marneffei. PLoS Pathogens, 1(2), e20.

Fontaneto D, Herniou EA, Boschetti C et al. (2007) Independently evolving species in asexual bdelloid rotifers. PLoS Biology, 5(4), e87.

Gardes M, Bruns TD (1993) ITS primers with enhanced specificity for basidiomycetesapplication to the identification of mycorrhizae and rusts. Molecular Ecology, 2, 113-118.

Gavrilets S (2004) Fitness Landscapes and the Origin of Species. Princeton University Press, Princeton, NJ.

Gavrilets S, Losos JB (2009) Adaptive radiation: contrasting theory with data. Science, 323, 732-737.

Giraud T (2004) Patterns of within population dispersion and mating of the fungus Microbotryum violaceum parasitising the plant Silene latifolia. Heredity, 95, 559-565.

Giraud T (2006a) Selection against migrant pathogens: the immigrant inviability barrier in pathogens. Heredity, 97, 316-318.

Giraud T (2006b) Speciation in parasites: host switching does not automatically lead to allopatry. Trends in Parasitology, 22, 151-152. 
Version définitive du manuscrit publié dans / Final version of the manuscript published in : Molecular Ecology, 2011, Article first published online, DOI: 10.1111/j.1365-294X.2011.05007.x. The definitive version is available at www3.interscience.wiley.com.

Giraud T, Villaréal L, Austerlitz F, Le Gac M, Lavigne C (2006) Importance of the life cycle in host race formation and sympatric speciation in parasites. Phytopathology, 96, 280-287.

Giraud T, Enjalbert J, Fournier E, Delmotte F, Dutech C (2008a) Population genetics of fungal diseases of plants. Parasite, 15, 449-454.

Giraud T, Refrégier G, de Vienne DM, Le Gac M, Hood ME (2008b) Speciation in fungi. Fungal Genetics \& Biology, 45, 791-802.

Giraud T, Gladieux P, Gavrilets S (2010) Linking emerging diseases and speciation. Trends in Ecology and Evolution, 25, 387-395.

Glawe DA (2008) The powdery mildews: a review of the world's most familiar (yet poorly known) plant pathogens. Annual Review of Phytopathology, 46, 27-51.

Hardy OJ, Vekemans X (2002) SPAGeDi: a versatile computer program to analyse spatial genetic structure at the individual of population levels. Molecular Ecology Notes, 2, 618-620.

Harvey NG (2006) Characterization of six polymorphic microsatellite loci from Ampelomyces quisqualis, intracellular mycoparasite and biocontrol agent of powdery mildew. Molecular Ecology Notes, 6, 1188-1190.

Hendry AP, Day T (2005) Population structure attributable to reproductive date: isolation-bytime and adaptation-by-time. Molecular Ecology, 14, 901-916.

Holb IJ (2005) Effect of pruning on disease incidence of apple scab and powdery mildew in integrated and organic apple production. International Journal of Horticultural Science, 11, 57-61.

Huson DH, Bryant D (2006) Application of phylogenetic networks in evolutionary studies. Molecular Biology and Evolution, 23, 254-267.

Johnson PA, Hoppensteadt FC, Smith JJ, Bush GL (1996) Conditions for sympatric speciation: a diploid model incorporating habitat fidelity and non-habitat assortative mating. Evolutionary Ecology, 10, 187-205.

Jombart T (2008) Adegenet: a R package for the multivariate analysis of genetic markers. Bioinformatics, 24, 1403-1405.

Kiss L (1998) Natural occurrence of Ampelomyces mycoparasites in mycelia of powdery mildew fungi. New Phytologist, 140, 709-714.

Kiss L (2001) The role of hyperparasites in host plant-parasitic fungi relationships. In: Biotic Interactions in Plant-Pathogen Associations (eds Jeger MJ, Spence NJ), pp. 227-236. CABI, Wallingford.

Kiss L (2008) Intracellular mycoparasites in action: interactions between powdery mildew fungi and Ampelomyces. In: Stress in Yeasts and Filamentous Fungi (eds Avery SV, Stratford M, Van West P), pp. 37-52. Academic Press, Elsevier, London.

Kiss L, Nakasone KK (1998) Ribosomal DNA internal transcribed spacer sequences do not support the species status of Ampelomyces quisqualis, a hyperparasite of powdery mildew fungi. Current Genetics, 33, 362-367.

Kiss L, Russell JC, Szentiványi O, Xu X, Jeffries P (2004) Biology and biocontrol potential of Ampelomyces mycoparasites, natural antagonists of powdery mildew fungi. Biocontrol Science \& Technology, 14,635-651.

Kondrashov AS, Mina MV (1986) Sympatric speciation: when is it possible? Biological Journal of the Linnean Society, 27,201-223.

Le Gac M, Giraud T (2008) Existence of a pattern of reproductive character displacement in Basidiomycota but not in Ascomycota. Journal of Evolutionary Biology, 21, 761-772.

Legendre P, Legendre L (1998) Numerical Ecology. Developments in Environmental Modelling, 20. Elsevier, Amsterdam

Levene H (1953) Genetic equilibrium when more than one ecological niche is available. American Naturalist, 87, 331-333. 
Version définitive du manuscrit publié dans / Final version of the manuscript published in : Molecular Ecology, 2011, Article first published online, DOI: 10.1111/j.1365-294X.2011.05007.x. The definitive version is available at www3.interscience.wiley.com.

Liang C, Yang J, Kovács GM, Szentiványi O, Li B et al. (2007) Genetic diversity of Ampelomyces mycoparasites isolated from different powdery mildew fungi in China inferred from analyses of rDNA ITS sequences. Fungal Diversity, 24, 225-240.

Loiselle BA, Sork VL, Nason J, Graham C (1995) Spatial genetic structure of a tropical understory shrub, Psychotria officinalis (Rubiaceae). American Journal of Botany, 82, 14201425.

de Meeûs T, Michalakis Y, Renaud F (1998) Santa Rosalia revisited: or why are there so many kinds of parasites in 'The garden of earthly delights?' Parasitology Today, 14, 10-13.

Montarry J, Cartolaro P, Delmotte F, Jolivet J, Willocquet L (2008) Genetic structure and aggressiveness of Erysiphe necator populations during grapevine powdery mildew epidemics. Applied and Environmental Micro biology, 74,6327-6332.

Montarry J, Cartolaro P, Richard-Cervera S, Delmotte F (2009) Spatio-temporal distribution of Erysiphe necator genetic groups and their relationship with disease levels in vineyards. European Journal of Plant Pathology, 123, 61-70.

Nilsson RH, Kristiansson E, Ryberg M, Hallenberg N, Larsson KH (2008) Intraspecific ITS variability in the Kingdom Fungi as expressed in the international sequence databases and its implications for molecular species identification. Evolutionary Bioinformatics, 4, 193-201.

Nischwitz C, Newcombe G, Anderson CL (2005) Host specialization of the mycoparasite Eudarluca caricis and its evolutionary relationship to Ampelomyces. Mycological Research, 109, 421-428.

Park M-J, Choi Y-J, Hong S-B, Shin H-D (2010) Genetic variability and mycohost association of Ampelomyces quisqualis isolates inferred from phylogenetic analyses of ITS rDNA and actin gene sequences. Fungal Biology, 114,235-247.

R Development Core Team (2010) R: A Language and Environment for Statistical Computing. R Foundation for Statistical Computing, Vienna, Austria.

Savolainen V, Anstett M-C, Lexer C etal. (2006) Sympatric speciation in palms on an oceanic island. Nature, 441,210-213.

Seifert KA, Wingfield BD, Wingfield MJ (1995) A critique of DNA sequence analysis in the taxonomy of filamentous Ascomycetes and ascomycetous anamorphs. Canadian Journal of Botany, 73(Suppl. 1), S760-S767.

Spratt BG, Hanage WP, Li B, Aanensen DM, Feil EJ (2004) Displaying the relatedness among isolates of bacterial species - the eBURST approach. FEMS Microbiology Letters, 241, 129-134.

Staden R, Beal KF, Bonfield JK (2000) The Staden package, 1998. Methods in Molecular Biology, 132, 115-130.

Stamm P (1983) The evolution of reproductive isolation in closely adjacent plant populations through differential flowering time. Heredity, 50, 105-118.

Sullivan RF, White Jr JF (2000) Phoma glomerata as a mycoparasite of powdery mildew. Applied and Environmental Micro biology, 66, 425-427.

Swofford DL (2003). PAUP*. Phylogenetic Analysis Using Parsimony (*and Other Methods), Version 4. Sinauer Associates, Sunderland, MA.

Szentiványi O, Kiss L (2003) Overwintering of Ampelomyces mycoparasites on apple trees and other plants infected with powdery mildews. Plant Pathology, 53, 737-746.

Szentiványi O, Kiss L, Russell JC et al. (2005) Ampelomyces mycoparasites from apple powdery mildew identified as a distinct group based on single-stranded conformation polymorphism analysis of the rDNA ITS region. Mycological Research, 109, 429-438.

Sztejnberg A, Galper S, Mazar S, Lisker N (1989) Ampelomyces quisqualis for biological and integrated control of powdery mildew in Israel. Journal of Phytopathology, 124, 285-295.

Tamura K, Dudley J, Nei M, Kumar S (2007) MEGA4: Molecular Evolutionary Genetics Analysis (MEGA) software version 4.0. Molecular Biology and Evolution, 24, 1596-1599. 
Version définitive du manuscrit publié dans / Final version of the manuscript published in : Molecular Ecology, 2011, Article first published online, DOI: 10.1111/j.1365-294X.2011.05007.x. The definitive version is available at www3.interscience.wiley.com.

Taylor JW (1999) The evolution of asexual fungi. Annual Review of Phytopathology, 37, 197246.

Théron A, Combes C (1995) Asynchrony of infection timing, habitat preference, and sympatric speciation of schistosome parasites. Evolution, 49, 372-375.

Thomas Y, Bethenoda M-T, Pelozuelo L, Frérot B, Bourguet D (2003) Genetic isolation between two sympatric host-plant races of the European corn borer, Ostrinia nubilalis Hubner. I. Sex pheromone, moth emergence timing, and parasitism. Evolution, 57, 261273.

Turner KME, Hanage WP, Fraser C, Connor TR, Spratt BG (2007) Assessing the reliability of eBURST using simulated populations with known ancestry. BMC Microbiology, 7, 30.

Van Putten WF, Elzinga JA, Biere A (2007) Host fidelity of the pollinator guilds of Silene dioica and S. latifolia: possible consequences for sympatric host race differentiation of a vectored plant disease. International Journal of Plant Science, 168, 421-434.

Vekemans X, Hardy OJ (2004) New insights from fine-scale spatial genetic structure analyses in plant populations. Molecular Ecology, 13, 921-935.

de Vienne DM, Refrégier G, Hood ME et al. (2009) Hybrid sterility and inviability in the parasitic fungal species complex Micro botryum. Journal of Evolutionary Biology, 22,683-698. 